\title{
The Effect of the Climatic and Topographic Conditions of Different Locations on the Geographical Fingerprints of EVOOS by using LC IMS Qtof Mass Spectrometry
}

\author{
Ayça AKÇA UÇKUN ${ }^{1 *}$, Berna ÖZALP ÖZEN ${ }^{2}$, Serap Bilgen ÇINAR ${ }^{2}$, Serap USTAOĞLU ${ }^{2}$, \\ Betül ÖZDEMĞ́ ${ }^{2}$, Nergiz Demirtaş ${ }^{2}$, Sibel PAZARLI ${ }^{2}$, Oya KÖSEOGLU1, Murat Güven \\ TUĞAÇ*3* \\ ${ }^{I}$ Republic of Turkey Ministry of Agriculture and Forestry, Olive Research Institute, Cultivation Techniques, \\ Bornova, Ġzir \\ ${ }^{2}$ Republic of Turkey Ministry of Agriculture and Forestry, Ankara Food Control Laboratory Directorate, \\ Yenimahalle, Ankara, Turkey \\ ${ }^{3}$ Republic of Turkey Ministry of Agriculture and Forestry, Geographical Information Department, Ankara, \\ Turkey \\ *Corresponding Authors: Ayça AKÇA UÇKUN, Republic of Turkey Ministry of Agriculture and \\ Forestry, Olive Research Institute, Cultivation Techniques, Bornova, İzmir \\ Murat Güven TU $\breve{G} A C ̧$, Republic of Turkey Ministry of Agriculture and Forestry, Geographical \\ Information Department, Ankara, Turkey
}

\begin{abstract}
The polyphenolic compounds and sterols present in six samples of olive fruits which obtained different climatic and topographic conditions in same region were analysed by LC IMS Qtof mass spectometry. All samples were collected same day during the normal picking period for olive oil production, in Karaburun region of Izmir provience and were obtained from the Erkence variety in six different olive location areas. In the Karaburun region samples, it was analyzed the obtained data using Progenesis QI software to analyze multivariate and to determine the geographical differences with help of statics on sterol and polyphenol profiles of olive oils. Results showed that Karaburun region is clustered significant quantitative differences of virgin olive oils (EVOOs) from different geographical locations. These results permit to use a successful distinction of EVOOs this research. It is recommended that olive oils to be labeled as geographical indication should be labeled on the basis of small local regions.
\end{abstract}

Keywords: climatic factors, topographic conditions, geographical fingerprints, geographical origin, geographical indication system (GIS), olive oil

\section{INTRODUCTION}

The Mediterranean diet is known among worldwide as a healthy diet. Olive, the most important type of the Mediterranean basin, has a widespread culture in this geography. EVOO (virgin olive oil) is known as the only vegetable oil obtained from olive tree fruits that can be consumed in its natural form (Fazio and Ricciardiello, 2014; Vasto et al., 2014). Quality of EVOO is affected by climatic and topographical conditions, cultivation methods, harvesting and olive oil processing processes (Angerosa et al., 2004). Olive oil contains $98 \%$ triglycerides, $2 \%$ phenolic substances, free fatty acids, sterols, hydrocarbons, aliphatic and triterpenic alcohols, volatile components and antioxidants (Servili and Montedero 2002). Total polyphenol content and phenolic composition of olives are depending on factors such as olive variety, climate (precipitation, temperature etc.), topography (slope, altitude). It is also known that phenolic substance concentrations change depending on the extraction conditions of EVOO (Kayahan and Tekin 2006). Phenolic substances not only affect the sensory properties of EVOOs, but also act as markers in distinguishing fruits belonging to different varieties (Romani et al., 1999).

Sterols are polycyclic alcohols in the chemically of group and they are known to contain compounds of sterane rings. Sterols are found in nature both in free form and in bound form esterified with fatty acids. Sterols are the most important component of the unsaponifiable substance that constitutes $0.5-1.5 \%$ of EVOOs. The amount and composition of sterols may vary depending on the agronomic conditions, climate, topography, quality of the fruit, the extraction and refining technique applied and the storage conditions of EVOOs (Canabate-Diaz et al., 2007). Determination of sterol composition is the most important method used to evaluate whether EVOOs are adulterated with other vegetable oils. In addition 
to some studies have shown that the geographical origin is effective on the steroid composition of EVOOs (Bagur-González et al., 2015; Ben Temine et al., 2008).

Similarly, EVOOs contain different phenolic substances such as phenolic acids, tyrosols/ hydroxytyrosols, flavonoids and lignanas. Phenolic compounds such as sterols are also affected by both genetic and environmental factors (Blasi et al., 2018). The composition and nutritional value of EVOOs vary depending on regional differences such as climate, soil, agricultural practices, and local varieties. The geographical origins of EVOOs are important which are the most appropriate parameter in determining the quality and commercial value (Woodcock et al.,2008).

In recent years, many studies have been conducted to improve the quality of EVOOs (Aparicio et al., 2013). According to these studies, not only the improvement of the quality of olive oils, but also the originality and the connection of geographical origin gained importance (Faria et al., 2010). In addition to using their own private brands, EVOOs producers use some labels to prove the uniqueness of climatic and topographic effects on their EVOOs. These labels are known as geographic indication. Recently, there has been an increasing interest in EVOOs, which are shown as certified as belonging to a single variety or whose geographic origin is indicated on the label. In the addition, the authentication of EVOOs has become important not only for producers but also for suppliers and administrative authorities, especially in relation to the protection of public health (Woodcock et al., 2008).

The European Union has made some arrangements for determining the origins of EVOOs and controlling the declarations regarding geographical indications (Woodcock et al., 2008). Geographical indications show that EVOOs are naturally connected with the characteristics of their geographical origins and the continuity of production with certain standardizations. Some tools have been developed that can help distinguish the reliability of geographically marked products, namely the origin-labeled olive oil from similar products. Among these tools, LC IMS Qtof mass spectrometry has been found quite successful (Longobardi et al., 2012). Olive oil leaders such as Spain, Italy and Greece are used not only to separate oils from different countries, but also to separate EVOOs based on location (Portarena et al., 2014). However, researchers has not been published the geographical indication characterization of EVOOs by using LC IMS Qtof mass spectrometry on literature in Turkey. In this study, the analysis of sterol and polyphenolic compounds of EVOOs obtained from olive cultivated in the same region but in different climatic and topographic conditions by using the appropriate extraction method by LC IMS Qtof mass spectrometry.

The aims of this study are to determine sterols and phenolic compounds in EVOOs by using LC IMS QTof mass spectrometry based method and detect marker ions for better classificating the geographical origin of EVOOs. Also, this study show the effects of topographic and climatic conditions of different locations on geographical origin.

\section{Materials AND Methods}

\subsection{Locations}

The study was carried out by the Olive Research Institute in 6 different locations (Eğlenhoca, Aşağıovacık, Kösedere, Haseki, Tepebozköy, Mordoğan) in the district of Karaburun in Izmir (Table 1). Karaburun was established on the $600 \mathrm{~km}^{2}$ Karaburun Peninsula which stretches towards the Aegean Sea of Izmir. The climate of the peninsula is Mediterranean Climate and the vegetation is a typical Mediterranean Vegetation. Summers are hot and dry, winters are warm and rainy. According to the averages of the last 5 years, the annual rainfall is $650-750 \mathrm{~mm}$, the lowest temperature is $-2{ }^{\circ} \mathrm{C}$ and the highest temperature is $35^{\circ} \mathrm{C}$ (Efe et al., 2012).

\subsection{Agricultural Ecological Maps}

In the study, agricultural ecological maps were created by means of GIS (figure 1). In these maps, similar homogeneous areas were created by combining the climate, topographic, soil and land cover parameters, which constitute the land features, by means of GIS (table 1). The classification system is based on the UNESCO (1979) system.

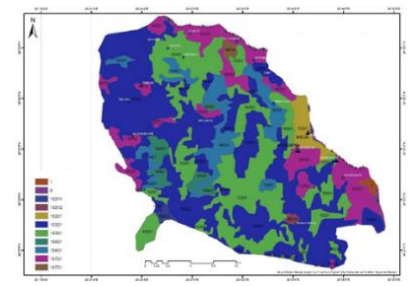

Figure1. Agricultural ecological map of Karaburun region. 
The Effect of the Climatic and Topographic Conditions of Different Locations on the Geographical Fingerprints of EVOOS by using LC IMS Qtof Mass Spectrometry

Table1. Agricultural ecological map information by using GIS (geographical information system)

\begin{tabular}{|l|l|l|l|l|l|l|}
\hline Karaburun & $\begin{array}{l}\text { Ecological } \\
\text { Map }\end{array}$ & Altitude & $\begin{array}{l}\text { Drought } \\
\text { Index }\end{array}$ & $\begin{array}{l}\text { Warmest } \\
\text { Average }\end{array}$ & $\begin{array}{l}\text { Coldest } \\
\text { Average }\end{array}$ & Slope \\
\hline Tepebozköy & 10331 & $300-500 \mathrm{~m}$ & $\begin{array}{l}0,5-0,75 \\
\text { (semi humid) }\end{array}$ & $>20^{\circ} \mathrm{C}$ & $0-10^{\circ} \mathrm{C}$ & $\% 12-30$ \\
\hline Eğlenhoca & 10331 & $300-500 \mathrm{~m}$ & $\begin{array}{l}0,5-0,75 \\
\text { (semi humid) }\end{array}$ & $>20^{\circ} \mathrm{C}$ & $0-10^{\circ} \mathrm{C}$ & $\% 12-30$ \\
\hline Kösedere & 10721 & $100-300 \mathrm{~m}$ & $\begin{array}{l}0,75-1 \\
\text { (humid) }\end{array}$ & $20-30^{\circ} \mathrm{C}$ & $0-10^{\circ} \mathrm{C}$ & $\% 2-12$ \\
\hline Haseki & 10331 & $0-100 \mathrm{~m}$ & $\begin{array}{l}0,5-0,75 \\
\text { (semi humid) }\end{array}$ & $>20^{\circ} \mathrm{C}$ & $0-10^{\circ} \mathrm{C}$ & $\% 12-30$ \\
\hline Ambarseki & 10431 & $300-500 \mathrm{~m}$ & $\begin{array}{l}0,5-0,75 \\
\text { (semi humid) }\end{array}$ & $>20^{\circ} \mathrm{C}$ & $0-10^{\circ} \mathrm{C}$ & $\% 12-30$ \\
\hline Mordoğan & 10721 & $0-100 \mathrm{~m}$ & $\begin{array}{l}0,75-1 \\
\text { (humid) }\end{array}$ & $>20^{\circ} \mathrm{C}$ & $0-10^{\circ} \mathrm{C}$ & $\% 12-30$ \\
\hline
\end{tabular}

\subsection{Olive Variety}

The locations selected in the study, consist of Erkence olive cultivar orchards. Erkence olive variety is known as the fastest ripening olive in the Aegean region. Erkence olive variety is grown in Seferihisar, Urla, Çeşme and Karaburun districts in İzmir's Karaburun peninsula. The fat content exactly varies between $24 \%$ and $25 \%$. One of the most important features of olives is that they can be eaten comfortably without sweetening (Tutar, 2010).

\subsection{Olive Oil Samples}

The olives were collected, at the same stage of maturity (The olives used for oil extraction had the following ripeness indices: 2.70-4,05) from 6 different locations in the Karaburun (Eğlenhoca, Aşağıovacık, Kösedere, Haseki, Tepebozköy, Mordoğan) and the same laboratory mill was used to prepare the olive oil samples. The olives were picked by hand from three trees during harvest season. After harvesting, using an Abencor analyser (1.5-2.0 kg) of olives were washed and deleafed, crushed with a hammer crusher, and the paste mixed at $25{ }^{\circ} \mathrm{C}$ for $30 \mathrm{~min}$, centrifuged without addition of warm water (oil produced from each extraction was $200-250 \mathrm{~mL} / \mathrm{kg}$ ) (Ouni et al., 2011) and then transferred into dark glass bottles, and stored in the dark at $4{ }^{\circ} \mathrm{C}$ until analysis.

\subsection{Chemicals}

Methanol of LC grade used for the extraction of sterols and phenolics from samples and preparing the mobile phase were supplied from Isolab (). Deionized water was obtained by filtration using a Milli-Qsystem (Millipore, Bedford, MS, USA). Ammonium acetate used for preparing the mobile phase was purchased from Sigma Aldrich (St. Louis, MO, USA).

\subsection{Extraction of Sterols and Phenolic Compounds}

Extraction of sterols and phenolic compounds from EVOOs was carried out using liquid extraction method as it has been described by Mohamed et al. 2018. MeOH:H2O (80:20, v/v) was used as the extraction solvent. Three grams of olive oil samples weighted into centrifuge tube, and added with 3 $\mathrm{mL}$ of $80 \% \mathrm{MeOH}$ solution. After homogenization via vortex, samples were centrifuged for $10 \mathrm{~min}$ at $7500 \mathrm{rpm}$. The supernatant was collected, the pellet was used again. The same procedure was repeated 3 times. All supernatant fractions were collected, combined and filtered through 0,22 $\mu \mathrm{m}$ PTFE syringe filters and stored in vial until LC IMS QTof analysis. The extracts obtained were mixed with an equal volume of water prior to analysis. Also, a pool sample consisting of all oil samples was prepared in the same way to check the accuracy of our research.

\subsection{LC IMS QTof Screening}

The LC IMS QTof system (Ultra-high performance liquid chromatography with a ACQUITY UHPLC I-Class system (Waters, Milford, MA, USA) was coupled to a VION® IMS QTof (Waters, Manchester, UK), ion mobility Quadrupole Time-of-Flight) was used. The LC separation was performed using an Acquity UPLC BEH C18 (100x2,1 mm, id. 1,7 $\mu \mathrm{m}$ particle size, Waters) analytical column. The oven was set at $30{ }^{\circ} \mathrm{C}$. The solvents used consisted of (A) $90 \% \mathrm{H} 2 \mathrm{O}, 10 \% \mathrm{MeOH}$, and $5 \mathrm{mM}$ ammonium 
The Effect of the Climatic and Topographic Conditions of Different Locations on the Geographical Fingerprints of EVOOS by using LC IMS Qtof Mass Spectrometry

aceate and (B) $100 \% \mathrm{MeOH}$ and $5 \mathrm{mM}$ ammonium aceate. The used flow gradient started with $1 \%$ solvent B with flow rate $0.35 \mathrm{~mL} / \mathrm{min}$ during $1 \mathrm{~min}$, increasing to $39 \%$ fort he following two $\mathrm{min}$ and then incereasing to $99 \%$ fort the next $11 \mathrm{~min}$. Organic conditions were kept for 2 min and then initial conditions were restored within $0.1 \mathrm{~min}$ and the column re-equilibrated for $2.5 \mathrm{~min}$. The total elution programme was $18 \mathrm{~min}$. The injection volume was $3 \mu \mathrm{L}$. The QTof system was operated in positive ionization mode, capillary voltage of $3.0 \mathrm{kV}$, mass range $50-1200 \mathrm{~m} / \mathrm{z}$. source temperature of $120{ }^{\circ} \mathrm{C}$, desolvation temperature of $400^{\circ} \mathrm{C}$. External calibration was performed using a Leu-enkephalin solution injected during the run 1 min intervals. Data were collected under low collision energy of $6.0 \mathrm{eV}$ and high collision energy of 15 to $45 \mathrm{eV}$ (Table 2).

Olive oil samples were analyzed in Waters brand Vion LC IMS QTof system (Waters, Milford, MA, USA) in order to determine the origin (Table 2 and 3).

Table2. The operating conditions of the Vion LC IMS QTof system

\begin{tabular}{|l|l|l|l|}
\hline Sample manager: & IMS QTof: & Column manager: & Scan settings: \\
\hline Wash solvent: Metanol:Su & Analyzer mode: & Temperature: $30{ }^{\circ} \mathrm{C}$ & Scan settings: $50 \mathrm{~m} / \mathrm{z}-$ \\
$(70: 30, \mathrm{v} / \mathrm{v})$ & Sensitivity & & $1200 \mathrm{~m} / \mathrm{z}$ \\
Sample temperature: $8.0^{\circ} \mathrm{C}$ & Capillary voltage: 3.0 & & High Deffinition $\mathrm{MS}^{\mathrm{E}}$ \\
& $\mathrm{kV}$ & & Low energy: $6.00 \mathrm{eV}$ \\
& Source temperature: 120 & & High energy ramp: $15-$ \\
& ${ }^{\circ} \mathrm{C}$ & & $15 \mathrm{eV}$ \\
& Desolvation & & \\
& temperature: $400{ }^{\circ} \mathrm{C}$ & & \\
& Cone gas: $50 \mathrm{~L} / \mathrm{h}$ \\
& Desolvation gas: 1000 & & \\
& L/h & & \\
\hline
\end{tabular}

Table3. Flow gradient of Vion LC IMS Qtof system

\begin{tabular}{|l|l|l|l|l|}
\hline Time $(\mathrm{dk})$ & Flow $(\mathrm{mL} / \mathrm{dk})$ & \% A & \% B & Curve \\
\hline 0.00 & 0.350 & 99.0 & 1.0 & 6 \\
\hline 1.00 & 0.350 & 99.0 & 1.0 & 6 \\
\hline 3.00 & 0.350 & 61.0 & 39.0 & 6 \\
\hline 14.00 & 0.350 & 1.0 & 99.0 & 6 \\
\hline 16.00 & 0.350 & 1.0 & 99.0 & 6 \\
\hline 16.01 & 0.350 & 99.0 & 1.0 & 6 \\
\hline 18.00 & 0.350 & 99.0 & 1.0 & 6 \\
\hline
\end{tabular}

All samples were analyzed in the same batch without any stopping. Data acquisition and data analysis were carried out by UNIFI (Waters, USA) software. Then, the raw datas were subjected to principal component analysis (PCA) using Progenesis QI (Nonlinear Dynamics, Waters, USA) software. UNIFI data format were converted to .uep format using the peak picking options.

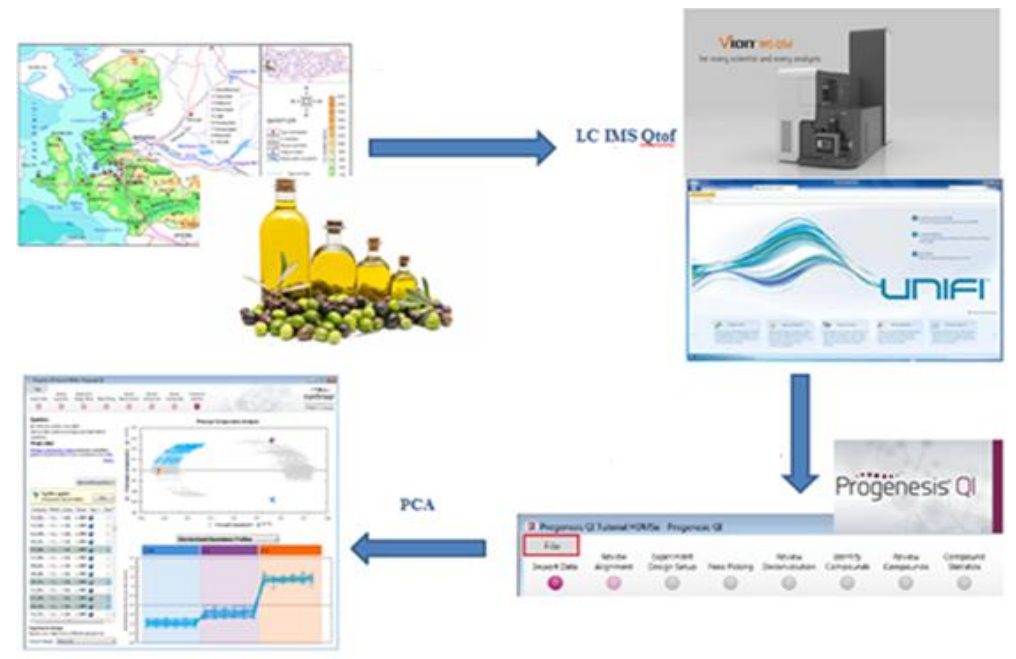

Figure2. Flow chart of this study conducted to determine marker ions in olive oils. 


\section{RESULTS AND DiSCUSSION}

\subsection{Effect of Olive Locations}

There are Tepebozköy, Aşağı ovacık and Ambarseki locations at an altitude of 300-500 m above sea level. Among these locations, the latest phenology was seen in Tepebozköy. The reason for this was revealed to be the highest altitude and slope (12-20\%) (Table 1). The high slope appears as the intake of plant nutrients is difficult and the water in the soil cannot hold. As the altitude increases, the temperature decreases and the upper limit of olive growth is determined accordingly. Slope plays a role by affecting the soil and groundwater in the cultivation of olive (Uslu, 1971).

Yield trees are seen in places where the slope is low, and inefficient trees are seen in the regions with high slope (Kaya, 2010). There are Mordoğan and Haseki villages at an altitude of 0-100 m above sea level. The reason that Mordoğan village is ahead of Haseki village in terms of phenology is that Mordoğan is the closest village to sea level and the drought index is humid according to the ecological map, making olive phenology come to the fore (Table 1). Kösedere village, which is located at 100-300 $m$ above sea level, is located in a humid zone with its slope (2-12\%) and drought index according to the agricultural ecological map. Humidity from the sea and large water surfaces is beneficial for olives. In humid weather, the sweating of the leaves of the tree decreases and there is no shortage of thirst. When olive tree leaves cannot get enough moisture from the soil in summer, they benefit from the moisture in the air. In olive cultivation, the relative humidity of the air is one of the criteria that increase olive quality. In areas where relative humidity is sufficient, the water consumption of the olive is also decreasing (Table 1) (Ayaz and Varol 2015).

\subsection{Determination of Marker Ions in EVOOs by using LC IMS QTof Screening}

The determination of marker ions in olive oils carried out using LC IMS QTof mass spectrometry system (Figure 3).
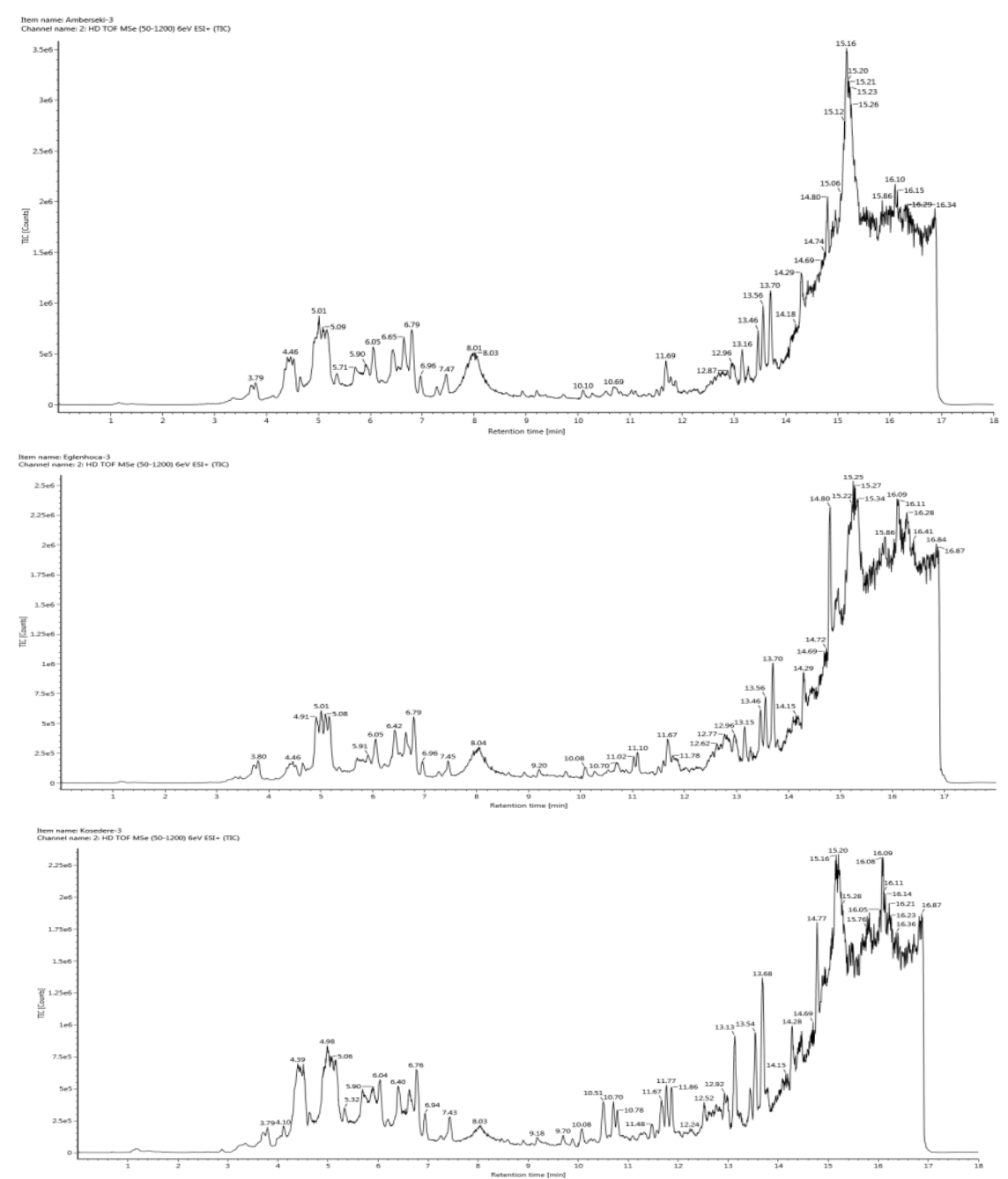
The Effect of the Climatic and Topographic Conditions of Different Locations on the Geographical Fingerprints of EVOOS by using LC IMS Qtof Mass Spectrometry
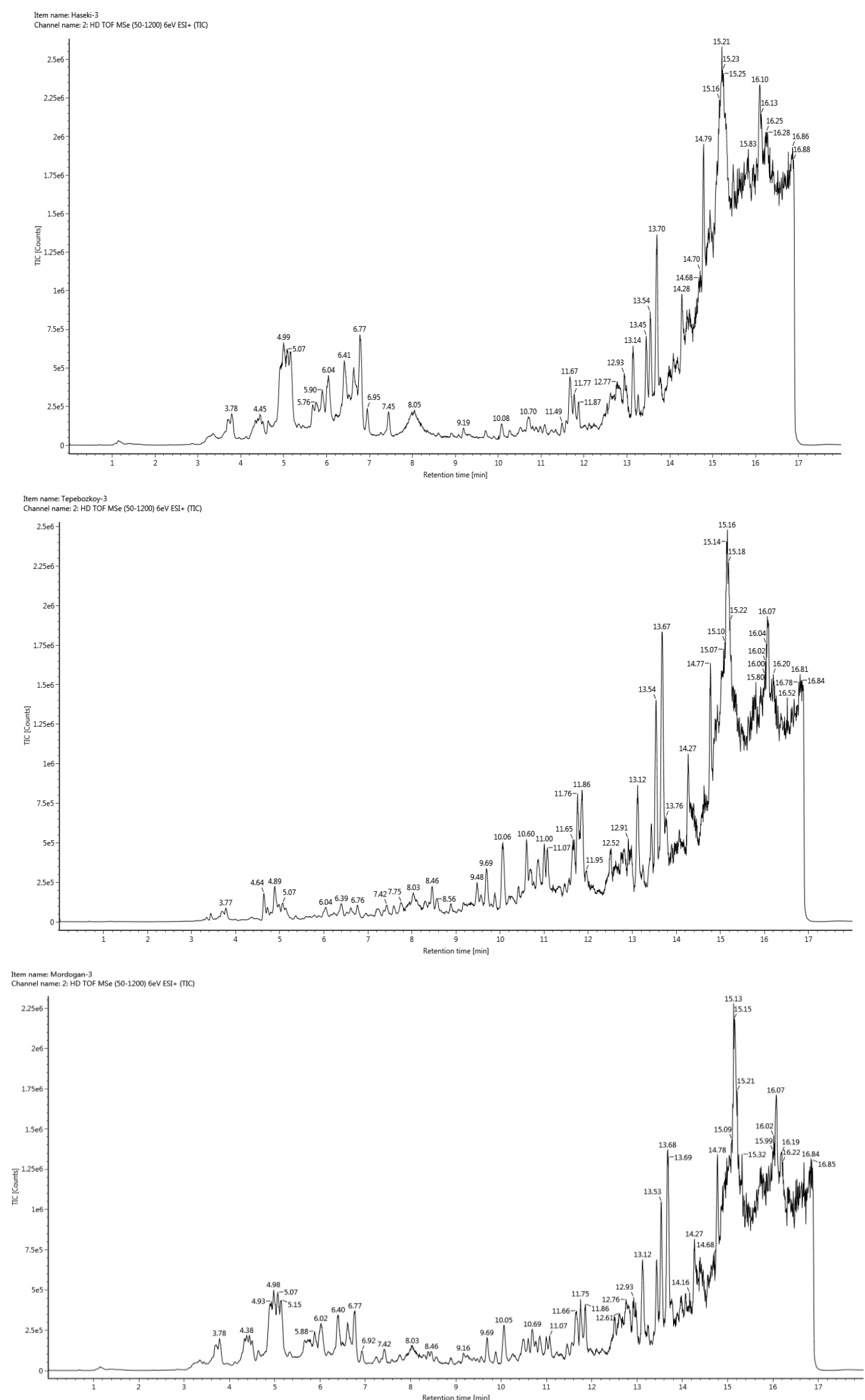

Figure3. Peak intensity chromatograms of EVOOs (A-Amberseki, B-Eğlenhoca, C-Haseki, D-Kösedere, ETepebozköy, F-Mordoğan, G-Pool) from ultra-performance liquid chromatography-quadrupole time-of-flight $M S$ in ESI+ ionization mode.

As can be seen in Figure 4, there are some differences among the olive oil extracts. A distinct clustering among the EVOOs was detected, which suggest that the metabolites significantly changed between different regions. 
The Effect of the Climatic and Topographic Conditions of Different Locations on the Geographical Fingerprints of EVOOS by using LC IMS Qtof Mass Spectrometry

\subsection{Statistical Analysis using Progenesis QI Software}

Progenesis QI software is widely used in metabolomics researches in recent years. In this study, Progenesis QI was used for multivariate statistical analysis. The spectral regions before $1.0 \mathrm{~min}$ and after $13 \mathrm{~min}$ of analysis were excluded from data evaluation.
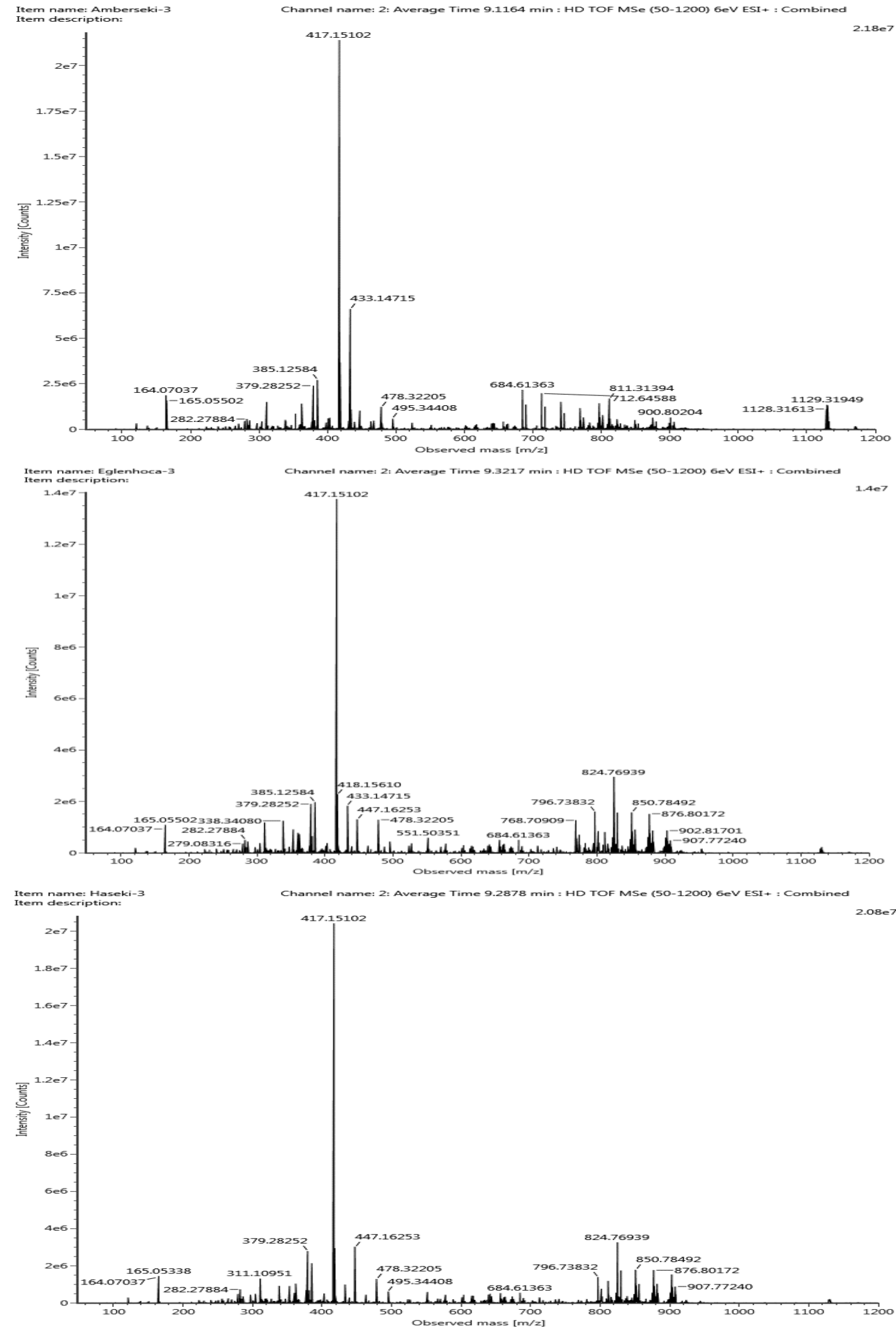
The Effect of the Climatic and Topographic Conditions of Different Locations on the Geographical Fingerprints of EVOOS by using LC IMS Qtof Mass Spectrometry
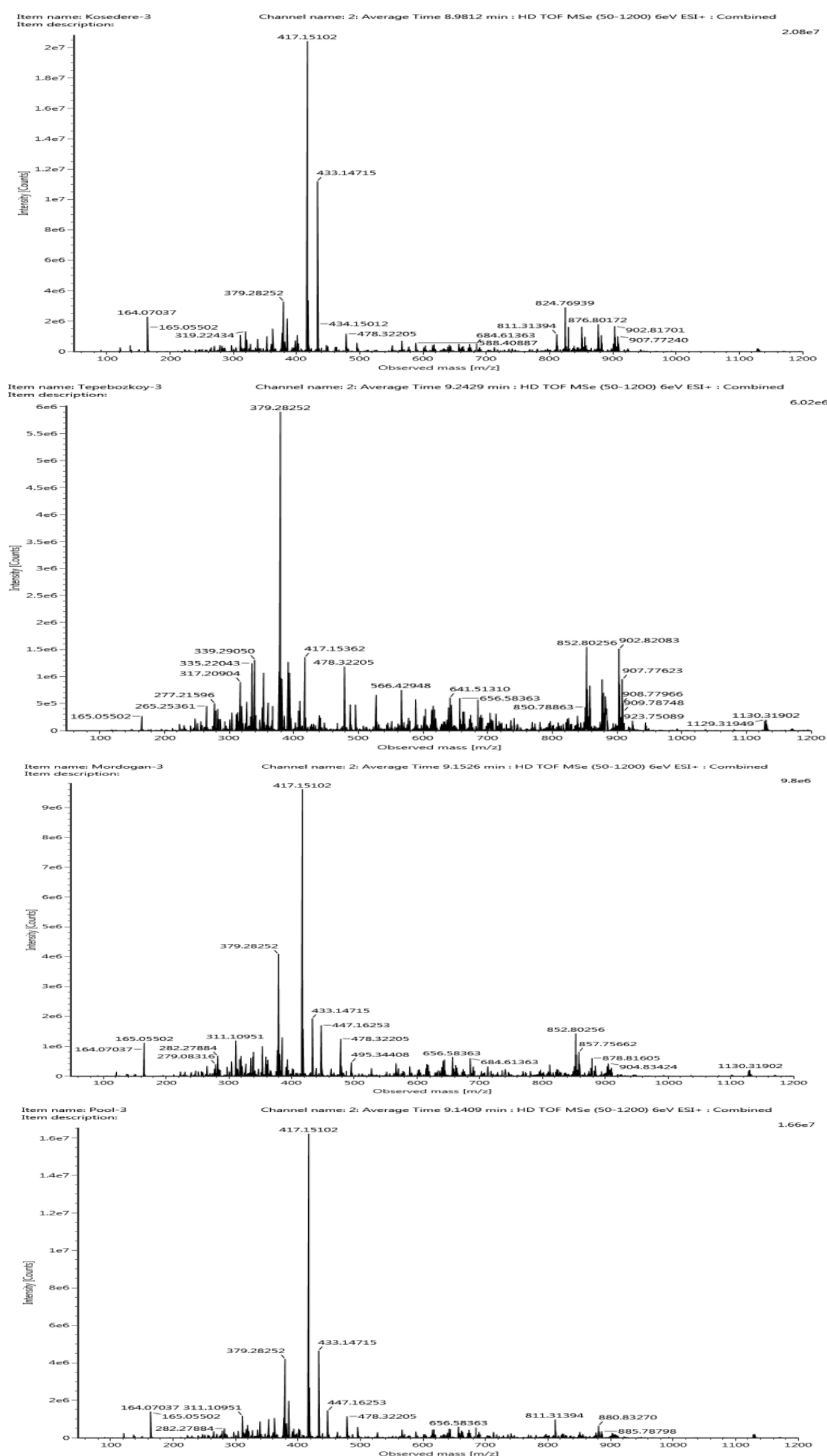

Figure4. ESI (+) - MS spectra of olive oils from Karaburun region. 
The data obtained from the principal component analysis showed that the secondary metabolites of olive oils such as sterols and phenolics are affected by the geographical area (Figure 4). Figure 4 shows the PCA score plot clearly classifying the EVOOs.
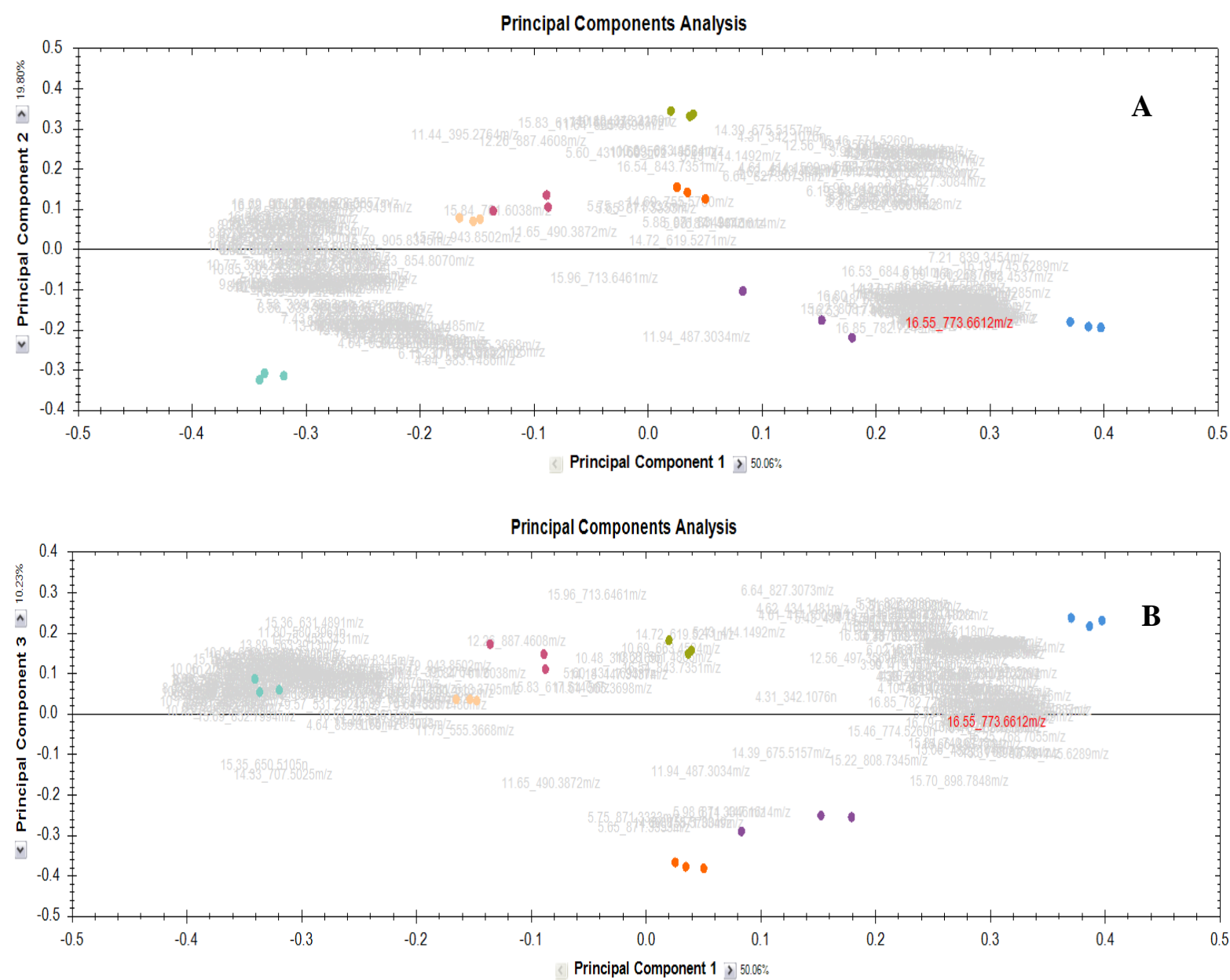

Figure5. (A) The plot is based on the first 2 principal component for data obtained in ESI+ mode (B) The plot is based on the first and third principal component for data obtained in ESI+ mode.

\section{A: PCA1 x PCA2 B:PCA1 x PCA3}

Pool samples were located in the centre of the PCA pilot shows that the analytical system is reliable. The samples in the same group are clustered together. PCA1, PCA2, PCA3 were used to show the clustring of the EVOOs. PCA1, PCA2 and PCA3 were $71.24 \%, 13.35 \%$ and $5.99 \%$, respectively. The total variance was determined as $90.58 \%$ at $95 \%$ confidence level. As can be seen in the PCA plot, it seems feasible to seperate the oil samples using this method (Figure 5).

The obtained data were filtered with anova $\mathrm{p}(\mathrm{p}$ value $\leq 0.05$ ), not fragmented and max-fold change. The markers in each sample were identified using EZ Info software. In this study, we used a method for untargeted metabolomics in EVOOs. The detected masses were then subjected to library scanning. Chemspider Library, Lipidblast Library, NIST MS/MS Library and elemental composition (H, C, N, O, $\mathrm{P}$ and $\mathrm{H}, \mathrm{C}, \mathrm{N}, \mathrm{O}$, separately) were used for scanning. The compounds were summarized along peak number, retention time, observed $\mathrm{m} / \mathrm{z}$, empirical formula, adduct, mass error, and $\mathrm{mSigma}$, isotope similarity ratio (\%) score and proposed compounds in Table 4. During the data processing and compounds identification, same compounds have different RT but have the same $\mathrm{m} / \mathrm{z}$ ratio. These results inferred that these compounds might be isomers. As a result of the library scanning, only one isomer with the highest isotope similarity ratio is shown in the Table 4.

As a result, each olive oil samples belonging to the Karaburun region is clustered in different regions. It has been determined that especially EVOOs belonging to Tepebozköy and Amberseki are clustered in quite different regions from the others, and a successful distinction can be made with this research. 
The Effect of the Climatic and Topographic Conditions of Different Locations on the Geographical Fingerprints of EVOOS by using LC IMS Qtof Mass Spectrometry

It has been determined that different climatic and topographical conditions cause differences in the geographical origin of EVOOs. In this respect, it is recommended that EVOOs to be labeled as geographical indication should be labeled on the basis of small local regions.

Table 4. Proposed marker ions identified in different regions using UPLC-ESI-Q-TOF-MS and Progenesisi-QI software.

\begin{tabular}{|c|c|c|c|c|c|c|c|c|c|}
\hline $\begin{array}{l}\mathrm{N} \\
\mathrm{O}\end{array}$ & Regions & $\begin{array}{l}\text { RT } \\
(\mathrm{mi} \\
\mathrm{n})\end{array}$ & $\mathrm{m} / \mathrm{z}$ & Formula & Adduct & $\begin{array}{l}\text { Mas } \\
\text { s } \\
\text { error } \\
(\mathrm{pp} \\
\mathrm{m}) \\
\end{array}$ & $\begin{array}{l}\mathrm{mSig} \\
\mathrm{ma} \\
\text { Score }\end{array}$ & $\begin{array}{l}\text { Isotope } \\
\text { Similari } \\
\text { ty }(\%)\end{array}$ & $\begin{array}{l}\text { Proposed } \\
\text { Compound }\end{array}$ \\
\hline 1 & \multirow{7}{*}{ Kösedere } & 3.97 & $\begin{array}{l}419,316 \\
3\end{array}$ & $\mathrm{C}_{25} \mathrm{H}_{38} \mathrm{O}_{3}$ & $\begin{array}{l}\mathrm{M}+\mathrm{CH}_{3} \mathrm{OH} \\
+\mathrm{H}\end{array}$ & 1.76 & 34.7 & 75.56 & CSID201317 \\
\hline 2 & & 4.09 & $\begin{array}{l}462.149 \\
2\end{array}$ & & & & & & \\
\hline 3 & & 4.18 & $\begin{array}{l}434.152 \\
3\end{array}$ & $\begin{array}{l}\mathrm{C}_{12} \mathrm{H}_{24} \mathrm{~N}_{3} \mathrm{O} \\
{ }_{10} \mathrm{P}\end{array}$ & $\mathrm{M}+\mathrm{NH}_{4}$ & $-\overline{2.81}$ & 38.7 & 96,89 & $\begin{array}{l}\mathrm{C} 12 \mathrm{H} 24 \mathrm{~N} 3 \mathrm{O} 1 \\
0 \mathrm{P}\end{array}$ \\
\hline 4 & & $\begin{array}{l}10.6 \\
7\end{array}$ & $\begin{array}{l}561.486 \\
7\end{array}$ & & & & & & \\
\hline 5 & & $\begin{array}{l}10.6 \\
8\end{array}$ & $\begin{array}{l}640.462 \\
9 n\end{array}$ & & & & & & \\
\hline 6 & & $\begin{array}{l}10.9 \\
8\end{array}$ & $\begin{array}{l}513.352 \\
0\end{array}$ & $\mathrm{C}_{30} \mathrm{H}_{50} \mathrm{O}_{5}$ & $\mathrm{M}+\mathrm{Na}$ & - & 33.7 & 75.43 & $\begin{array}{l}\text { DG(18:4/9:0/0: } \\
0)\end{array}$ \\
\hline 7 & & $\begin{array}{l}12.2 \\
6 \\
\end{array}$ & $\begin{array}{l}887.460 \\
9\end{array}$ & & & & & & \\
\hline 8 & $\begin{array}{l}\text { Amberse } \\
\mathrm{ki}\end{array}$ & 7.72 & $\begin{array}{l}1038.63 \\
04\end{array}$ & & & & & & \\
\hline 9 & Haseki & 4.05 & $\begin{array}{l}479.149 \\
7\end{array}$ & & & & & & \\
\hline 10 & \multirow{15}{*}{$\begin{array}{l}\text { Tepebozk } \\
\text { öy }\end{array}$} & 4.62 & $\begin{array}{l}441,342 \\
1\end{array}$ & & & & & & \\
\hline 11 & & 4.62 & $\begin{array}{l}859.315 \\
0\end{array}$ & & & & & & \\
\hline 12 & & 4.71 & $\begin{array}{l}799.293 \\
3\end{array}$ & & & & & & \\
\hline 13 & & 4.96 & $\begin{array}{l}305.100 \\
5\end{array}$ & $\mathrm{C}_{16} \mathrm{H}_{16} \mathrm{O}_{6}$ & $\mathrm{M}+\mathrm{H}$ & $\begin{array}{l}- \\
4.82\end{array}$ & 37.2 & 82.84 & $\begin{array}{l}\text { CSID2236972 } \\
9\end{array}$ \\
\hline 14 & & 5.09 & $\begin{array}{l}607,214 \\
8\end{array}$ & $\begin{array}{l}\mathrm{C}_{25} \mathrm{H}_{37} \mathrm{~N}_{4} \mathrm{O} \\
{ }_{10} \mathrm{P}\end{array}$ & $\mathrm{M}+\mathrm{Na}$ & 1.51 & 38.7 & 95.52 & $\begin{array}{l}\text { C25H37N4O1 } \\
\text { 0P }\end{array}$ \\
\hline 15 & & 6.04 & $\begin{array}{l}352.222 \\
4 n\end{array}$ & & & & & & \\
\hline 16 & & 8.89 & $\begin{array}{l}407.239 \\
8\end{array}$ & $\mathrm{C}_{19} \mathrm{H}_{27} \mathrm{~N}_{5} \mathrm{O}_{4}$ & $\mathrm{M}+\mathrm{NH}_{4}$ & $\overline{-}-9.93$ & 37.9 & 90,45 & C19H27N504 \\
\hline 17 & & 9.33 & $\begin{array}{l}409,252 \\
9\end{array}$ & $\begin{array}{l}\mathrm{C}_{15} \mathrm{H}_{34} \mathrm{~N}_{10} \\
\mathrm{O}\end{array}$ & $\mathrm{M}+\mathrm{K}$ & 1.77 & 38.7 & 95.72 & $\mathrm{C} 15 \mathrm{H} 34 \mathrm{~N} 10 \mathrm{O}$ \\
\hline 18 & & 9.44 & $\begin{array}{l}637.391 \\
3 \\
\end{array}$ & $\mathrm{C}_{30} \mathrm{H}_{62} \mathrm{O}_{11}$ & $\mathrm{M}+\mathrm{K}$ & $-\overline{1.79}$ & 36.3 & 83.58 & $\begin{array}{l}\text { Decapropylene } \\
\text { glycol }\end{array}$ \\
\hline 19 & & 9.45 & $\begin{array}{l}531.292 \\
2\end{array}$ & $\begin{array}{l}\mathrm{C}_{22} \mathrm{H}_{40} \mathrm{~N}_{10} \\
\mathrm{O}_{3}\end{array}$ & $\mathrm{M}+\mathrm{K}$ & 1.14 & 39.1 & 96.83 & $\begin{array}{l}\mathrm{C} 22 \mathrm{H} 40 \mathrm{~N} 10 \mathrm{O} \\
3\end{array}$ \\
\hline 20 & & 9.94 & $\begin{array}{l}661,354 \\
9\end{array}$ & & & & & & \\
\hline 21 & & $\begin{array}{l}10.2 \\
7\end{array}$ & $\begin{array}{l}635.376 \\
0\end{array}$ & $\mathrm{C}_{34} \mathrm{H}_{50} \mathrm{O}_{9}$ & $\begin{array}{l}\mathrm{M}+\mathrm{CH}_{3} \mathrm{OH} \\
+\mathrm{H}\end{array}$ & $-\overline{4,83}$ & 51,6 & 67,49 & C34H50O9 \\
\hline 22 & & $\begin{array}{l}10.4 \\
8 \\
\end{array}$ & $\begin{array}{l}631,380 \\
1\end{array}$ & $\mathrm{C}_{31} \mathrm{H}_{61} \mathrm{O}_{8} \mathrm{P}$ & $\mathrm{M}+\mathrm{K}$ & $\begin{array}{l}11.1 \\
1 \\
\end{array}$ & 35.2 & 87.83 & $\begin{array}{l}\text { GPA(10:0- } \\
18: 0)\end{array}$ \\
\hline 23 & & $\begin{array}{l}10.5 \\
1 \\
\end{array}$ & $\begin{array}{l}619,377 \\
9 \\
\end{array}$ & $\mathrm{C}_{40} \mathrm{H}_{52} \mathrm{O}_{4}$ & $\mathrm{M}+\mathrm{Na}$ & 3.52 & 33.7 & 72.61 & Astoxanthin \\
\hline 24 & & $\begin{array}{l}10.5 \\
3\end{array}$ & $\begin{array}{l}615,349 \\
3\end{array}$ & $\begin{array}{l}\mathrm{C}_{33} \mathrm{H}_{52} \mathrm{~N}_{2} \mathrm{O} \\
9\end{array}$ & $\mathrm{M}+\mathrm{Na}$ & $-\overline{1.78}$ & 38.1 & 92.51 & CSID389429 \\
\hline
\end{tabular}


The Effect of the Climatic and Topographic Conditions of Different Locations on the Geographical Fingerprints of EVOOS by using LC IMS Qtof Mass Spectrometry

\begin{tabular}{|c|c|c|c|c|c|c|c|c|}
\hline 25 & $\begin{array}{l}10.5 \\
6\end{array}$ & $\begin{array}{l}647,372 \\
2\end{array}$ & $\begin{array}{l}\mathrm{C}_{31} \mathrm{H}_{52} \mathrm{NO}_{1} \\
{ }_{0} \mathrm{P}\end{array}$ & $\mathrm{M}+\mathrm{NH}_{4}$ & 8.75 & 33.2 & 75.71 & $\begin{array}{l}\text { GPSer(18:4/7: } \\
0)\end{array}$ \\
\hline 26 & $\begin{array}{l}11.3 \\
1\end{array}$ & $\begin{array}{l}588.358 \\
7\end{array}$ & $\mathrm{C}_{30} \mathrm{H}_{51} \mathrm{O}_{8} \mathrm{P}$ & $\mathrm{M}+\mathrm{NH}_{4}$ & $\begin{array}{l} \\
12.7 \\
5\end{array}$ & 32.2 & 74.46 & GPA(18:4/9:0) \\
\hline 27 & $\begin{array}{l}11.3 \\
1 \\
\end{array}$ & $\begin{array}{l}611,355 \\
2\end{array}$ & $\begin{array}{l}\mathrm{C}_{28} \mathrm{H}_{52} \mathrm{NO}_{1} \\
{ }_{0} \mathrm{P}\end{array}$ & $\mathrm{M}+\mathrm{NH}_{4}$ & $\begin{array}{l}19.3 \\
9 \\
\end{array}$ & 33.1 & 84.66 & $\begin{array}{l}\text { GPSer(14:1/8: } \\
0)\end{array}$ \\
\hline 28 & $\begin{array}{l}11.3 \\
6\end{array}$ & $\begin{array}{l}625,333 \\
0\end{array}$ & $\mathrm{C}_{34} \mathrm{H}_{50} \mathrm{O}_{9}$ & $\mathrm{M}+\mathrm{Na}$ & $\begin{array}{l} \\
2.76\end{array}$ & 56.9 & 92.02 & C34H50O9 \\
\hline 29 & $\begin{array}{l}11.6 \\
4 \\
\end{array}$ & $\begin{array}{l}589,369 \\
3 \\
\end{array}$ & $\begin{array}{l}\mathrm{C}_{29} \mathrm{H}_{50} \mathrm{NO}_{8} \\
\mathrm{P}\end{array}$ & $\mathrm{M}+\mathrm{NH}_{4}$ & $\begin{array}{l}14.0 \\
8\end{array}$ & 32.2 & 75.67 & $\begin{array}{l}\text { GPCho(18:4/3: } \\
0)\end{array}$ \\
\hline 30 & $\begin{array}{l}11.6 \\
7\end{array}$ & $\begin{array}{l}601,370 \\
9\end{array}$ & $\mathrm{C}_{33} \mathrm{H}_{54} \mathrm{O}_{8}$ & $\mathrm{M}+\mathrm{Na}$ & $\begin{array}{l}- \\
0.43\end{array}$ & 38.2 & 91.52 & $\begin{array}{l}\text { Timosponin A- } \\
\text { I }\end{array}$ \\
\hline 31 & $\begin{array}{l}11.7 \\
4 \\
\end{array}$ & $\begin{array}{l}649,389 \\
5 \\
\end{array}$ & $\begin{array}{l}\mathrm{C}_{31} \mathrm{H}_{54} \mathrm{NO}_{1} \\
{ }_{0} \mathrm{P}\end{array}$ & $\mathrm{M}+\mathrm{NH}_{4}$ & $\begin{array}{l}11.3 \\
5\end{array}$ & 32.1 & 72.95 & $\begin{array}{l}\text { GPSer(18:3/7: } \\
0)\end{array}$ \\
\hline 32 & $\begin{array}{l}11.7 \\
4\end{array}$ & $\begin{array}{l}721,483 \\
2\end{array}$ & $\mathrm{C}_{41} \mathrm{H}_{69} \mathrm{O}_{8} \mathrm{P}$ & $\mathrm{M}+\mathrm{H}$ & 4.10 & 32,3 & 66.07 & $\begin{array}{l}\text { GPA(22:6/16:0 } \\
\text { ) }\end{array}$ \\
\hline 33 & $\begin{array}{l}11.7 \\
9\end{array}$ & $\begin{array}{l}603,385 \\
6 \\
\end{array}$ & $\begin{array}{l}\mathrm{C}_{29} \mathrm{H}_{61} \mathrm{~N}_{2} \mathrm{O} \\
{ }_{6} \mathrm{P}\end{array}$ & $\mathrm{M}+\mathrm{K}$ & -7.57 & 37.2 & 94.46 & SM(d14:0/10:0 \\
\hline 34 & $\begin{array}{l}11.9 \\
8 \\
\end{array}$ & $\begin{array}{l}633,395 \\
8 \\
\end{array}$ & & & & & & \\
\hline 35 & $\begin{array}{l}12.3 \\
7 \\
\end{array}$ & $\begin{array}{l}735,501 \\
7 \\
\end{array}$ & $\begin{array}{l}\mathrm{C}_{37} \mathrm{H}_{67} \mathrm{NO}_{1} \\
2\end{array}$ & $\mathrm{M}+\mathrm{NH}_{4}$ & 2.20 & 34.3 & 73,89 & $\begin{array}{l}\text { Erythromycin: } \\
\text { 12-deoxy }\end{array}$ \\
\hline 36 & $\begin{array}{l}12.4 \\
1 \\
\end{array}$ & $\begin{array}{l}703,475 \\
0\end{array}$ & $\mathrm{C}_{43} \mathrm{H}_{68} \mathrm{O}_{5}$ & $\mathrm{M}+\mathrm{K}$ & 4.55 & 33.5 & 72,62 & $\begin{array}{l}\text { DG(18:2/22:6/ } \\
0: 0)\end{array}$ \\
\hline 37 & $\begin{array}{l}12.5 \\
9\end{array}$ & $\begin{array}{l}697.427 \\
7 \\
\end{array}$ & $\mathrm{C}_{36} \mathrm{H}_{66} 10$ & $\mathrm{M}+\mathrm{K}$ & $-\overline{1.54}$ & 36.4 & 83.66 & $\begin{array}{l}\text { MGDG(10:0/1 } \\
7: 1)\end{array}$ \\
\hline 38 & $\begin{array}{l}12.9 \\
9\end{array}$ & $\begin{array}{l}719,505 \\
6 \\
\end{array}$ & & & & & & \\
\hline
\end{tabular}

$*_{\mathrm{n}}$ : neutral mass

\section{FUNDING SOURCES}

This work has been carried out project no 1513, 'Investigation of Olive and Olive Oil with Regional Characteristics with Climatic and Topographic Conditions and Determination of Geographical Indication Standardization" by TAGEM (Agricultural Research Policies Directorate).

\section{ACKNOWLEDGMENTS}

The authors gratefully thank to Olive Research Institute, Ankara Food Control Laboratory Directorate, Origin Determination Laboratory Unit, Republic of Turkey Ministry of Agriculture and Forestry and olive farmers of Karaburun region.

\section{AbBreViations AND NOMENCLATURE}

GI :Geographical Indication; PCA :Principal Component Analysis; EVOO : Extra Virgin Olive Oil; RT : Retention Time; LC: Liquid Cromatography; IMS: Ion Mobility Spectrometry; QTof: Quadropole Time-of-Flight

\section{REFERENCES}

[1] Angerosa, F., Servili, M., Selvaggini, R., Taticchi, A., Esposto, S., and Montedoro, G. 2004. 495 Volatile compounds in virgin olive oil: occurrence and their relationship with the quality. 496 Journal of Chromatography A, 1054(1-2), 17-31. 497 http://doi.org/10.1016/j.chroma.2004.07.093

[2] Aparicio, R., Morales, M.T., Aparicio - Ruiz, R., Tena, N. and Gonzalez, D., 2013. Authenticity of olive oil: Mapping and comparing official methods and promising alternatives. Food Research International 54 (2): 2025-2038, DOI: 10.1016/j.foodies.2013.07.039

[3] Ayaz, M. and Varol, N. 2015. İklim Parametrelerindeki Değişimlerin (Sıcaklık, Yağış, Kar, Nispi Nem, Sis, Dolu ve Rüzgar) Zeytin Yetiştiriciliği Üzerine Etkileri, Zeytin Bilimi, Cilt 5, Sayı 1: 33-40.

[4] Bagur-González, M.G., Pérez-Castano, E., Sánchez-Vinas, M. and Gázquez-Evangelista, D. 2015. Using the liquid-chromatographic-fingerprint of sterols fraction to discriminate virgin olive from other edible oils. Journal of Chromatography A, 1380, 64-70. 
The Effect of the Climatic and Topographic Conditions of Different Locations on the Geographical Fingerprints of EVOOS by using LC IMS Qtof Mass Spectrometry

[5] Ben Temine, S., Manai, H., Methenni, K., Baccouri, B., Abaza, L., Daoud, D. and Zarrouk, M. 2008. Sterolic composition of Chétoui virgin olive oil: Influence of geographical origin. Food Chemistry, 110(2), 368-374.

[6] Blasi, F., Rocchetti, G., Montesano, D., Lucini, L., Chiodelli, G., Ghisoni, S. and Cossignani, L. 2018. Changes in extra-virgin olive oil added with Lycium barbarum L. carotenoids during frying: Chemical analysis and metabolomics approach. Food Research International, 105, 507-616.

[7] Canabate-Diaz, B., Carretero, A.S., Fernandez-Gutierrez, A., Vega, A.B., Frenich, A.G., Vidal, J.L.M. and Martos, J.D. 2007. Separation and determination of sterols in olive oil by HPLC-MS. Food Chemistry, 102; 593-598.

[8] Efe, R., Soykan, A., Cürebol, I. and Sönmez, S. 2012. Olive and olive oil culture in the Mediterranean basin. R. Efe, M. Özturk, S. Ghazanfar (eds.), Environment and Ecology in the Mediterranean Region, Cambridge Scholar Publishing, pp.51-62.

[9] Fazio, C., and Ricciardiello, L. 2014. Components of the Mediterranean Diet with 539 chemopreventive activity toward colorectal cancer. Phytochemistry Reviews, 13(4), $867-540 \quad 879$. http://doi.org/10.1007/s11101-014-9346-4

[10] Faria, M.A., Cunha, S.C., Paice, A.G. and Oliveira, M. 2010. Olive Oil Authenticity Evaluation by Chemical and Biological Methodologies, V.R. Preedy and R.R.Watson (eds), Olives and Olive Oil in Health and Disease Prevention, Academic Press, pp.101-107

[11] Kayahan, M. ve Tekin, A. 2006. Zeytinyağı Üretim Teknolojisi. TMMOB Gıda Mühendisleri Odası Kitaplar Serisi:15, Filiz Matbaacılık San. Tic. Ltd, 217s.,Ankara.

[12] Longobardi, F., Ventrella, A., Casiello, G., Sacco, D., Catucci, L., Agostiano, A. and Kontominas, M.G. 2012. Instrumental and multivariate statistical analyses for the characterisation of the geographical origin of Apulian virgin olive oils. Food Chemistry 133 (2012) 579-584.

[13] Mohamed, M.B, Rocchetti, G., Montesano, D., Ali, S.B., Guasmi, F., Grati-Kamoun, N. and Lucini, L. 2018. Discrimination of Tunisian and Italian extra-virgin olive oils according to their phenolic and sterolic fingerprints. Food Research International, 106; 920-927.

[14] Portarena, S., Gavrichkova, O., Lauteri, M. and Brugnoli, E. 2014. Authentication and traceability of İtalian extra-virgin olive oils by means of stable isotopes techniques, Food Chemistry 164 (2014) 12-16.

[15] Portarena, S., Farinelli, D., Lauteri, M., Famiani, F. Esti, M. and Brugnoli, E. 2015. Stable isotope and fatty acid compositions of monovarietal olive oils: Implications of ripening stage and climate effects as determinants in traceability studies. Food Control, 57, 129-135.

[16] Romani, A., Mulinacci, N., Pinelli, P., Vincieri, F. F. and Cimato, A. 1999. Polyphenolic content in five Tuscany cultivars of Olea europaea L. Journal of Agricultural and Food Chemistry, 47; 964-967.

[17] Servili, M. and Mondetero, G. F. 2002. Contribution of Phenolic Compounds to Virgin Olive Oil Quality. European Journal of Lipid Science and Technology, 104; 602-613.

[18] Tutar, M. 2010. Erkence Zeytin Çeşidinde Farklı Tiplerin Belirlenmesi. Ege Üniversitesi, Fen Bilimleri Enstitüsü, Doktora Tezi. Bornova/İzmir.

[19] Uslu, S. 1971. Ege Bölgesi ve Bilhassa Edremit Güre Havzasında Toprak Koruması Bakımından Zeytin ve Orman Münasebetleri. İstanbul Üniversitesi, Orman Fakültesi Dergisi

[20] Vasto, S., Buscemi, S., Barera, A., Di Carlo, M., Accardi, G., Caruso, C. 2014. Mediterranean 589 diet and healthy ageing: a Sicilian perspective. Gerontology, 60(6), 508-18. 590 http://doi.org/10.1159/000363060

[21] Woodcock, T., Downey, G. and O’Donnell, C.P. 2008. Confirmation of declared provenance of Eurupean extra virgin olive oil samples by NIR spectroscopy. Journal of Agricultural and Food Chemistry, 56, 1152011525

Citation: Ayça AKÇA UÇKUN,et.al., "The Effect of the Climatic and Topographic Conditions of Different Locations on the Geographical Fingerprints of EVOOS by using LC IMS Qtof Mass Spectrometry..", International Journal of Research in Environmental Science (IJRES), vol. 7, no. 3, pp. 1-12, 2021. Available: DOI: http://dx.doi.org/ 10.20431/2454-9444.0703001

Copyright: (C) 2021 Authors. This is an open-access article distributed under the terms of the Creative Commons Attribution License, which permits unrestricted use, distribution, and reproduction in any medium, provided the original author and source are credited. 